行なわれる加熱温度 $\left(150 \sim 160^{\circ} \mathrm{C}\right)$ においては, ジフェノ

一ル類はノボラックに含まれる末反応フェノールと異な

り加熱時間が長くさえあれば硬化する性質を有している ことがわかった。

付記：終りに種々ご指導いただいた鶴田博士に深謝す る。なお本研究は昭和 33 年 4 月日本化学会第 11 年会で請演し たものである。

\section{文献}

1) H.L. Bender: Mod. Plast., 115, Man (1954)

2) 瀨戸，堀内：工化, 56, 890(1953)

3) 横山: 高化, 16, 281 (1959)

4) 鶴田, 飯島, 古賀：工化，57，644(1954)

5) 横山: 高化, 12,271(1955)

6) 横山: 高化, 14, 394 (1957)

7) 横山：高化, 16, 369(1959)

8) 横山：高化, 15, 850 (1958)

\title{
Researches on the Hardening Reaction of Phenol Novolac
}

VIII. Hardening Reaction of Dihydroxydiphenylmethanes

By Ryoji Yokoyama* and Takahito Yamanishi**

The hardening reaction of dihydroxydiphenylmethanes (diphenols) and hexamine was examined by the method previously reported. The heat-hardened product of diphenol and hexamine exhibits different solubility according to the kind of solvent used. The product tends to become insoluble after the viscosity of the solution increases. 2,2 diphenol becomes insoluble most readily, while $2,4^{\prime}$ diphenol and $4,4^{\prime}$ diphenol seem to show the same ease of insolubility. Since rate constants of the hardening reaction with the formation of insoluble matter of those diphenols are found to be remarkably small in comparison with that of phenol novolac, it was shown that diphenols share no direct relation with the hardening reaction of novolac.

* Hitachi Taga Works Plastic Section (Kawarago-chō, Hitachi, Ibaragi)

** Hitachi Research Laboratory (Sukegawa-chō, Hitachi, Ibaragi)

$$
\text { 正 誤 表 }
$$

小田良平・時浦昌平・美安明・岡野正弥著「重樎合または重付加による高分子化合物の合成」に関し 著者より下記のとおり訂正がまいりましたのでお知せいたします。

\begin{tabular}{|c|c|c|c|}
\hline 巻, ページ & 行 & 誤 & 正 \\
\hline 16,141 & 文献 1) 2 行目 & 星野：日特, & 日特, \\
\hline$"$ & " 3 行目 & (1950) & $(1954)$ \\
\hline 142 & 英文要旨 6 行目 & ethyl- $\varepsilon$-aminocaproate & ethyl $\varepsilon$-aminocaproate \\
\hline 61,263 & 1. $4,1.7,1.10$ & o-アクリロイル- & O-アクリロイル- \\
\hline 265 & 右 7 行目 & 窒素ガン & 空素ガス \\
\hline$" \prime$ & 文献 6) & 高化, 15, & 高化, 16 , \\
\hline 267 & 右 6 行目 & 2 種または 2 種の結合 & 2 種または 3 種の結合 \\
\hline 269 & 1.11の見出し & [6-(カルペトキシアミノ)カルボヘキシル] & [6-(カルベトキシアミノ)カルボヘキソキシ] \\
\hline$" \prime$ & 1.12の見出し & [3-(6-カルペトキシペンチル)泉絜] & [3-(5-カルベトキシペンチル)尿素] \\
\hline 270 & 文献 1) & 高化, 15, & 高化, 16, \\
\hline
\end{tabular}

昭和 34 年 11 月 20 日印刷昭和 34 年 11 月 25 日 発行 第 16 巻 第 175 号

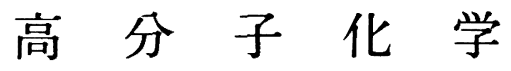
会員外 頒 価 130 円 編集兼発行人 荒井深 吉
印 刷 所 研究社印刷株式会社

発行所社団法人高分子学会 東京都中央区日本稩本町 3 の 9 繊維会館内 電話日本㛢 (24) 2793 振替東京111688 